\title{
Proximal and Distal Humerus Fractures in a Patient with Chronic Inflammatory Joint Disease Undergoing Biologic Therapy
}

Razvan Turcu ${ }^{1,2}$, Marius Moga $^{1,2}$, George Dinache ${ }^{1,2}$, Adrian Barbilian ${ }^{1,2}$

\begin{abstract}
Bone changes occurring in people with rheumatoid arthritis increase the incidence of fractures in these patients. In the complex fractures of the 3-part proximal humerus, the treatment of choice is represented by open reduction and osteosynthesis. Because of the important role of the distal portion of the humerus in the elbow joint, firm osteosynthesis with angularly blocked implants provides a superior biomechanics and stability in the treatment of complex fractures even in the elderly with a diminished bone stock due to osteoporosis. The preliminary diagnosis was established following simple radiographs. Establishing the diagnosis required computerized tomography and three-dimensional elbow reconstruction. Surgery was performed following the analysis of the imaging data, practicing the first step of reduction and osteosynthesis by the MIPO technique of the proximal humerus fracture, subsequent reduction and osteosynthesis of the distal humerus fracture, the defective bone was filled with artificial bone graft, and the osteosynthesis of the osteotomized olecan. Reduced soft tissue damage, reduced postoperative pain, reduced functional impairment, and axillary nerve protection confer superiority to osteosynthesis through the mini-invasive approach (MIPO) versus the transdeltoid approach.
\end{abstract}

Keywords: MIPO, 3D reconstruction computed tomography, rheumatoid arthritis, proximal humerus fracture, distal humerus fracture

\section{Rezumat}

Modificările ososase ce apar la persoanele cu poliartrită reumatoidă cresc incidența fracturilor la acești pacienți. În fracturile complexe ale humerusului proximal cu 3 fragmente, tratamentul de elecție este reprezentat de reducerea deschisă și osteosinteză. Datorită rolului important al porțiunii distale a humerusului, în cadrul articulației cotului, osteosinteza fermă prin plăci blocate premulate, angular stabile, oferă o biomecanică și o stabilitate superioară în tratamentul fracturilor complexe chiar și la persoanele în vârstă, cu un stoc osos diminuat din cauza osteoporozei. Diagnosticul preliminar a fost stabilit în urma efectuării radiografilor simple. Stabilirea diagnosticului a impus efectuarea unei tomografii computerizate și o reconstrucție tridimensională a cotului. Intervenția chirurgicală a fost efectuată în urma analizei datelor imagistice, practicându-se în primă etapă reducere și osteosinteză prin tehnica MIPO a fracturii de humerus proximal, ulterior reducerea și osteosinteza fracturii de humerus distal, plombajul defectului osos cu substituent și hobanajul olecranului osteotomizat. Lezarea redusă a țesuturilor moi, reducerea durerii postoperator, diminuarea gradului de insuficiență funcțională și protejarea nervului axilar conferă superioritate osteosintezei prin abordul miniminvaziv (MIPO) față de abordul transdeltoidian.

Cuvinte cheie: MIPO, reconstrucție 3D tomografie computerizată, poliartrită reumatoidă, fractura humerus proximal, fractură humerus distal

' Clinic of Orthopedics and Traumatology, "Carol Davila” University Central Military Emergency Hospital, Bucharest, Romania

2 "Carol Davila" University of Medicine and Pharmacy, Bucharest, Romania
Corresponding author.

Razvan Nicolae Turcu, Clinic of Orthopedics and Traumatology, "Carol Davila" University Central Military Emergency Hospital, Bucharest, Romania.

E-mail: razvan_turcu@yahoo.com 


\section{INTRODUCTION}

Rheumatoid arthritis affects women more frequently, aged 40 to 70, three times more frequently than men. Bone changes occurring in people with rheumatoid arthritis increase the incidence of fractures in these patients ${ }^{1}$.

In the complex fractures of the proximal 3 of the humerus, the treatment of choice is represented by open reduction and osteosynthesis. This method can also be applied minivasively, known as minimally invasive plate osteosynthesis (MIPO) $)^{2,3}$.

Stabilized anatomically and angulated locked plates allow the screws to be fixed in various planes, varying up to 30 degrees, having the role of an internal fixator. Their use reported results confirmed by numerous studies, representing the treatment of complex fracture at

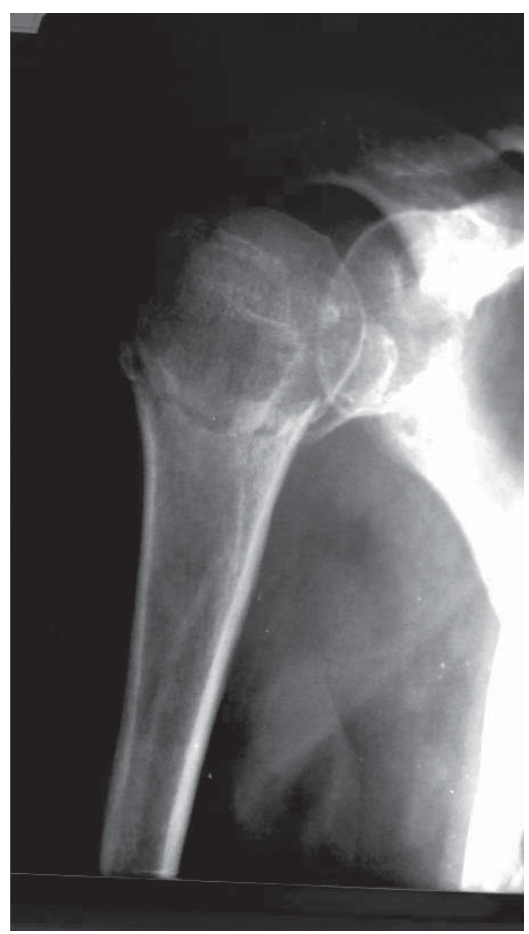

Figure 1. Antero-posterior shoulder radiography.

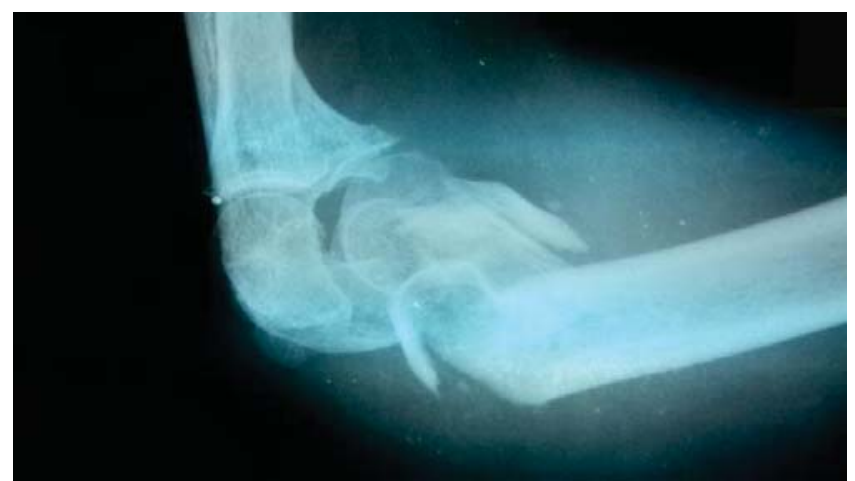

Figure 2. Radiography of right elbow joint profile.

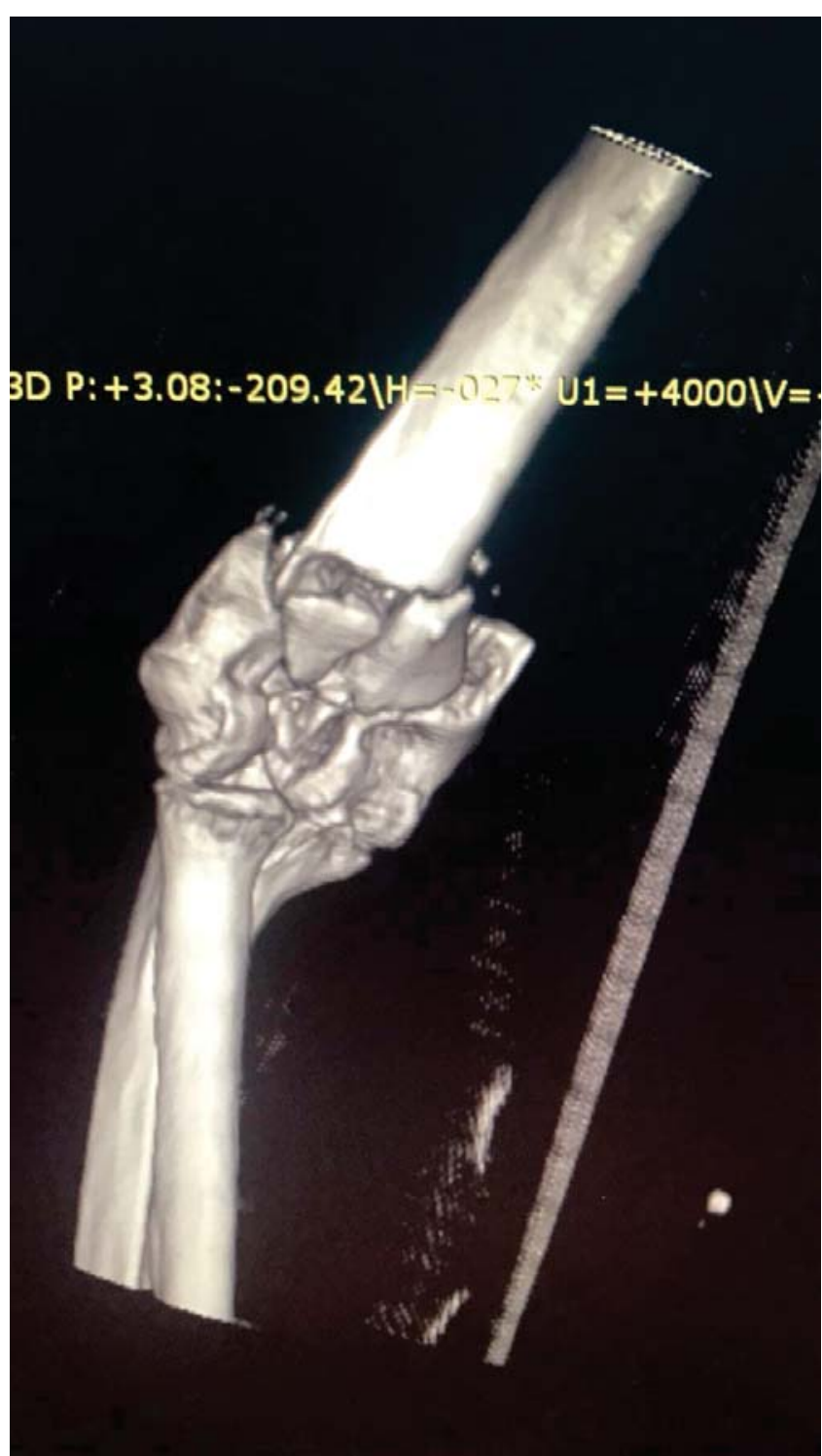

Figure 3. 3D reconstruction of computerized tomography right elbow.

different levels: distal femoral fractures, tibial plateau, tibial pilon, distal radial epiphysis, proximal humerus, distal humerus, clavicle ${ }^{4}$.

In the treatment of proximal humerus fractures, the literature highlights the superiority of osteosynthesis through the mini-invasive approach (MIPO) versus the transdeltoid approach. The advantages of using MIPO are reduced soft tissue damage, reduced postoperative pain, reduced functional impairment, axillary nerve protection ${ }^{2,5}$.

In the complex fractures of the humerus, the distal treatment of the choice is represented by open reduction and osteosynthesis ${ }^{6}$.

Because of the important role of the distal portion of the humerus within the elbow joint, new fixation techniques have been developed, such as stable locked pla- 


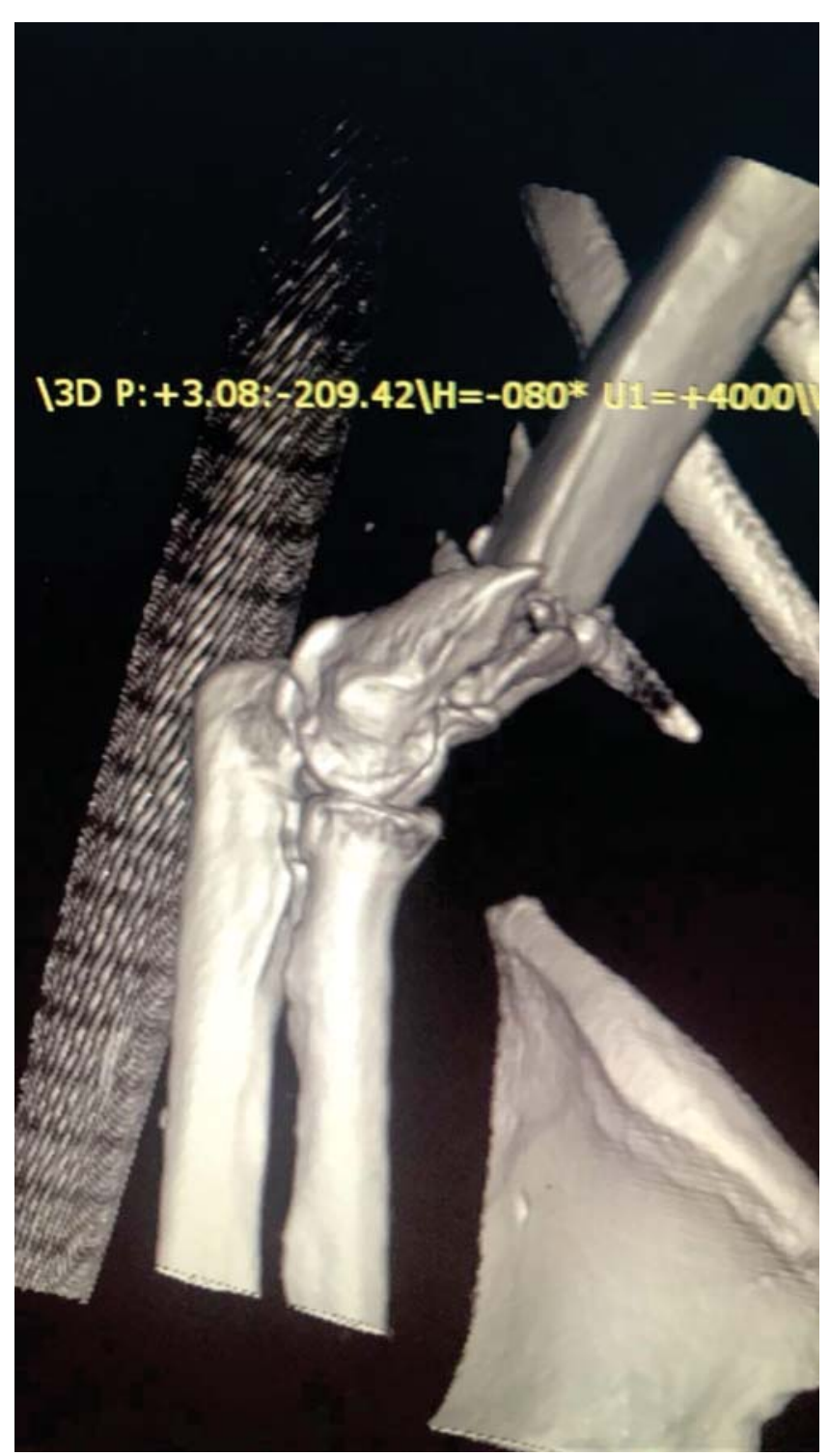

Figure 4. 3D reconstruction of computerized tomography right elbow.

te osteosynthesis ${ }^{7}$. anatomically precontoured locking plates offer a superior biomechanical and stability in the treatment of complex fractures even in the elderly with a diminished bone stock due to osteoporosis ${ }^{8}$.

\section{CASE REPORT}

A 60-year-old female patient, known for chronic hepatitis $\mathrm{C}$ virus with undetectable viremia, rheumatoid arthritis under biological therapy, ischemic cardiopathy, presented at the Emergency Room accusing pain and functional impotence of the right arm, after a fall injury from same level. The clinical examination revealed total functional impotence, arm and elbow, local shoulder and elbow deformity, abnormal mobility, massive

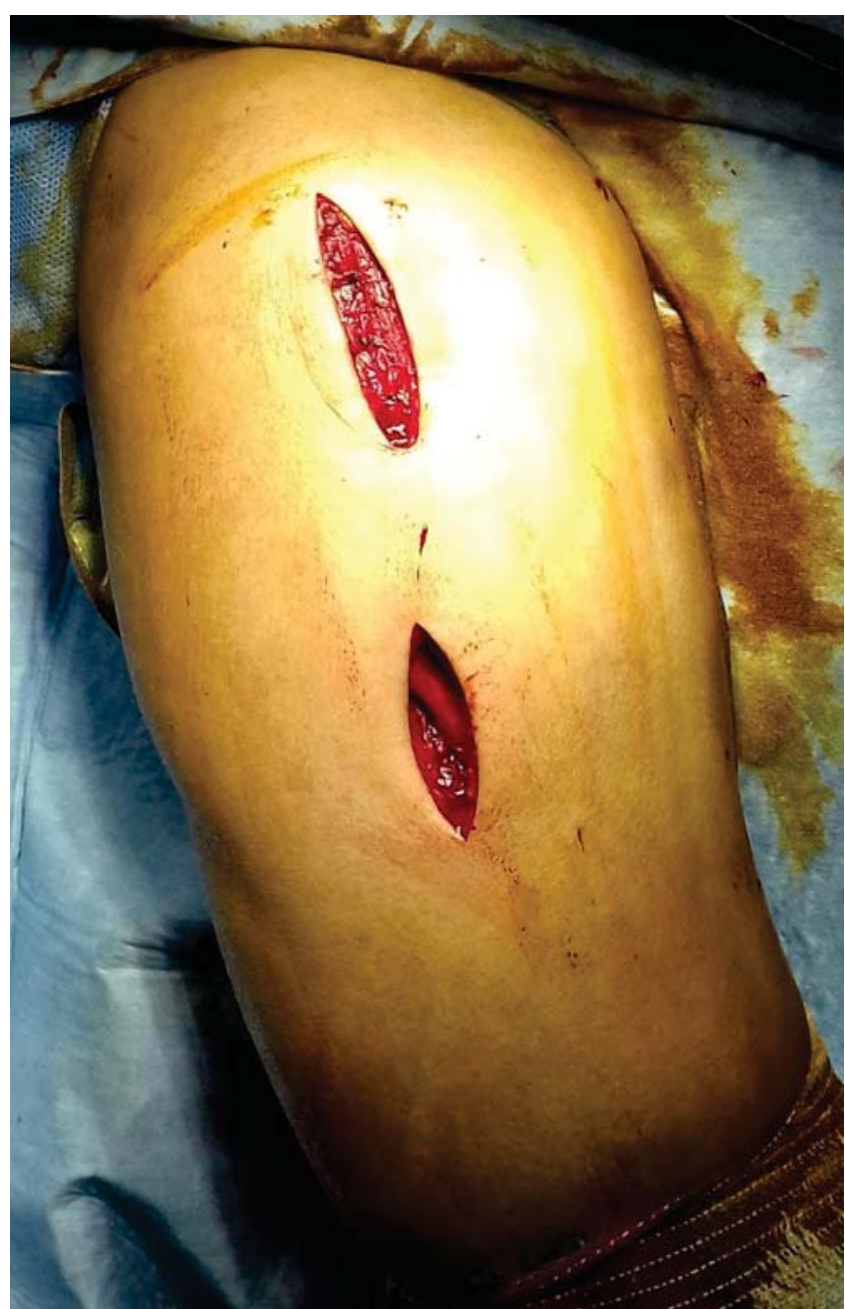

Figure 5. Intraoperative aspect MIPO approach of proximal humerus.

elbow and elbow echimosis. There were no phenomena of nervous damage.

The preliminary diagnosis was established following simple radiographs. Establishing the diagnosis required computerized tomography and three-dimensional elbow reconstruction.

The analysis of the three-dimensional reconstruction of computed tomography allowed the preoperative planning to be performed and the optimal therapeutic course to be established.

\section{MATERIALS AND METHODS}

The patient was positioned on a surgical table in a beach chair position for osteosynthesis by MIPO technique of the proximal humerus fracture, then in ventral decubitus for the posterior approach of the elbow, for the reduction and osteosynthesis of the distal humerus fracture. Surgery was performed under general 


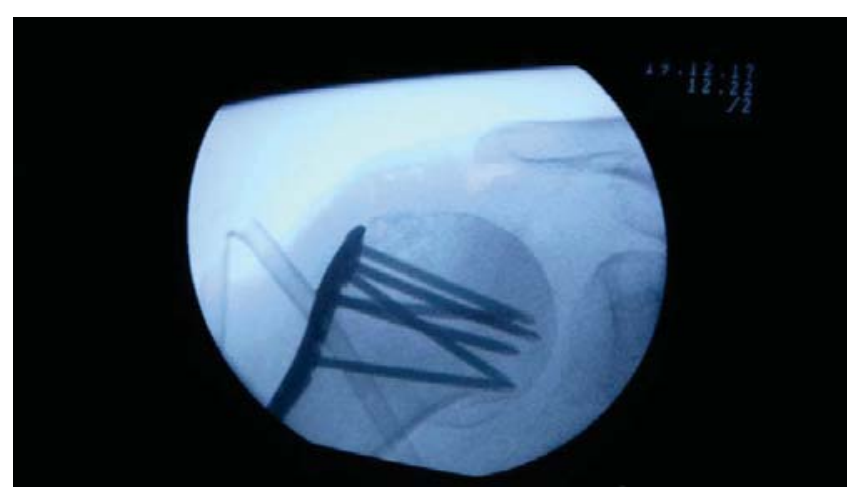

Figure 6. Intraoperative aspect - C-arm radiological control during proximal humerus osteosynthesis.

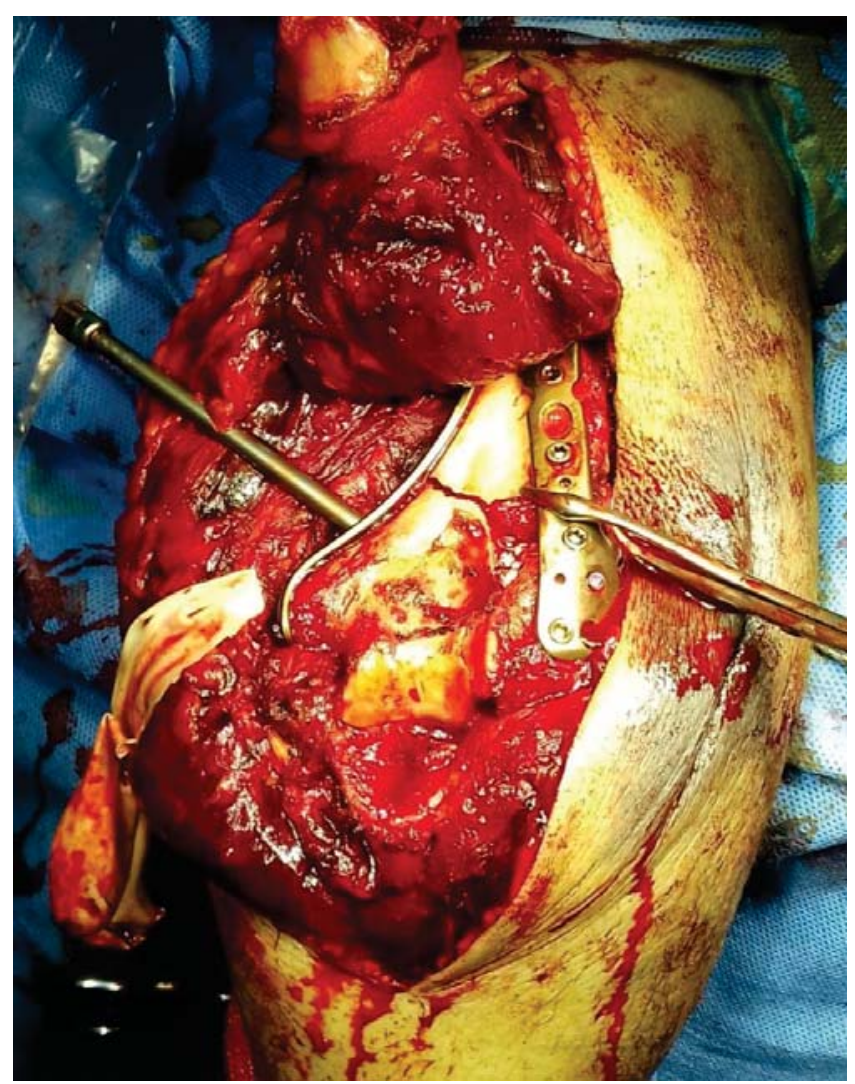

Figure 7. Intraoperative aspect - osteotomy of olecranon with retraction of insertion of brachial triceps, restoration of articular surface, distal humerus osteosynthesis with 2 locking plates, filling the bone defect with artificial bone graft.

anesthesia, a broad spectrum antibiotic for infection prophylaxis was administered 9 .

The approach used for the MIPO technique involves a minimal transdeltoid approach, approximately 5 centimeters distal to the edge of the acromion, and a metaphysis approach to fix the locking plate to the humeral diaphysis. The axillary nerve was protected by avoiding

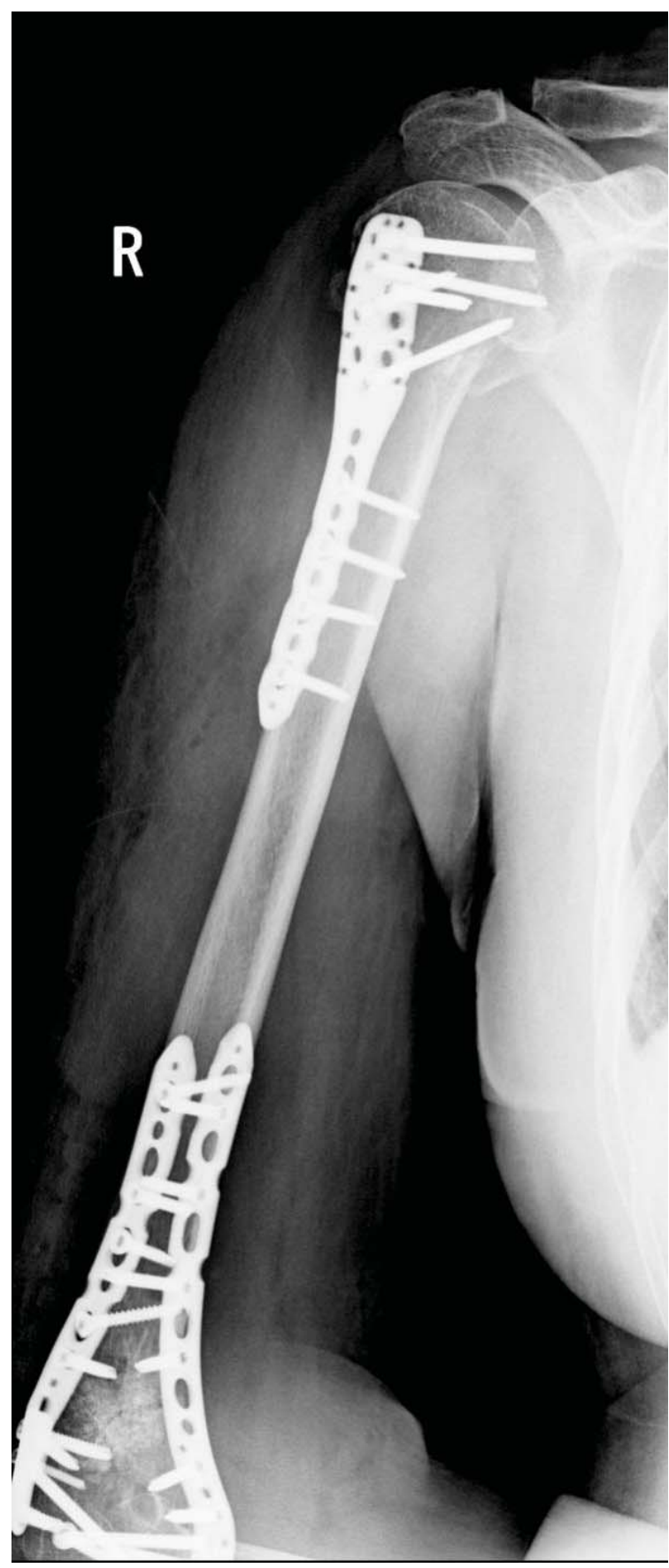

Figure 8. Anteroposterior elbow radiography - postoperative control profile radiography - postoperative control.

extensive dissection and retraction of the soft tissues of the two incisions, approximately 3 centimeters ${ }^{10}$.

Fracture reduction was achieved by axial stretch of the humerus and indirect reduction by ligamentotaxis by manipulation of the rotator cuff. Osteosynthesis by locking plating of the proximal humerus involves fixation of the locking plate proximally, just below the 

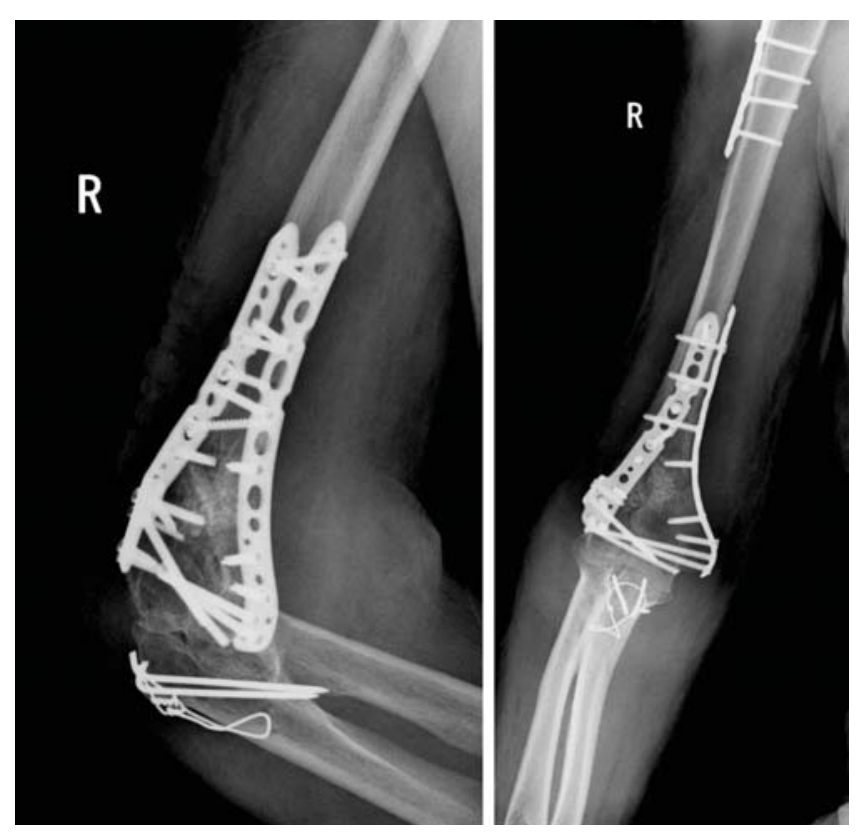

Figure 9. Anteroposterior radiography - postoperative control.

apex of greater tuberosity and non-resorbable suturing of the rotator cuff to the implant. Several stable angular screws are blocked at the humeral head ${ }^{11}$.

The posterior approach to the elbow was practiced. The "V” osteotomy of the olecranon was practiced to retract brachial triceps and have a good articular and distal humerus exposure ${ }^{12}$. After fracture reduction and restoration of articular surfaces, osteosynthesis was performed with 2 fixed angular locking plates respecting the $2 \mathrm{hu}-$ meral columns, and the defect was filled with a bone substitute, artificial bone graft. After the visualization of the radiological control, the olecran reduction was performed and fixed by tension band wiring ${ }^{13}$.

The postoperative recovery program involves passive movements after surgery, an immobilization in orthesis for 2 weeks, and active movements within the range of pain tolerance ${ }^{2}$.

\section{References}

1. Feehan, L.M., L.L. Li, and H.A. McKay, Micro-structural bone changes in early rheumatoid arthritis persist over 1-year despite use of disease modifying anti-rheumatic drug therapy. BMC Musculoskelet Disord, 2017. 18(1): p. 521

2. Lin, T., et al., Minimally invasive plate osteosynthesis with a locking compression plate is superior to open reduction and internal fixation in the management of the proximal humerus fractures. BMC Musculoskelet Disord, 2014. 15: p. 206.

3. Zhang, Q., et al., [Minimally invasive plate osteosynthesis for treatment of proximal humeral fractures through anterolateral acromial approach]. Beijing Da Xue Xue Bao Yi Xue Ban, 2017. 49(2): p. 242-245.

\section{DISCUSSIONS}

The mechanism underlying bone damage is the local response to cytokines, hypervascularization, periarticular bone edema, bone catabolism imbalance, bone demineralization in relation to sedentarism and the effects of rheumatoid arthritis ${ }^{1}$.

The standard deltopectoral approach for proximal humerus fractures offers limited access, so viewing the reduction of greater tuberosity can be difficult. The deltopectoral approach requires extensive soft tissue dissection and muscle retraction for adequate exposure to the lateral part of the humerus ${ }^{14}$.

This may have consequences on the fractured fracture vascularization during dissection, reduction and osteosynthesis, resulting in damage to the vascular support of the humeral head. The transdeltoid approach is an alternative that provides a view of the posterolateral portion of the shoulder, without extensive dissection and violent retraction of the soft parts. The inconvenience of applying this approach is the possibility of axillary nerve damage ${ }^{2,15}$.

MIPO provides a good view of the posterolateral surface of the huneral head through a reduced incision, avoiding extensive dissection of the soft tissue. Reducing the fractured greater tuberosity will be performed at sight, thus shortening the operator time required to reposition the fragment ${ }^{10}$.

\section{CONCLUSIONS}

The advantages of MIPO are lower intraoperative time than the classic reduction and osteosynthesis procedure, a lower amount of blood loss, a shorter relative hospitalization duration, a better pain score, a cosmetic aspect of postoperative scarring ${ }^{10}$.

The success of the treatment of distal distal humeral fractures is dependent on correct fracture diagnosis, a correct reduction with a reconstruction of the joint surfaces, a stable fixation of the fragments, and a functional recovery program with the fastest postoperative onset $^{4,16}$.

4. Cronlein, M., et al., Polyaxial locking plates in treating distal humeral fractures: a comparative randomized trial for clinical outcome. BMC Musculoskelet Disord, 2017. 18(1): p. 547.

5. Kanthimathi, B. and V. Narayanan, Minimal Invasive Plate Osteosynthesis (MIPO) Technique Using Anterolateral Approach for Treating Closed Proximal Humerus Fracture. Malays Orthop J, 2012. 6(1): p. 25-9

6. Atalar, A.C., et al., Biomechanical comparison of orthogonal versus parallel double plating systems in intraarticular distal humerus fractures. Acta Orthop Traumatol Turc, 2016.

7. Parmaksizoglu, A.S., et al., Fixation of extra-articular distal humeral fractures with a lateral approach and a locked plate: an 
Proximal and Distal Humerus Fractures in a Patient with Chronic Inflammatory Joint Disease Undergoing Biologic Therapy

alternative method. Acta Orthop Traumatol Turc, 2016. 50(2): p. 132-8.

8. Shannon, S.F., et al., Osteosynthesis of AO/OTA 13-C3 distal humeral fractures in patients older than 70 years. J Shoulder Elbow Surg, 2017.

9. Park, J. and S.Y. Jeong, Complications and outcomes of minimally invasive percutaneous plating for proximal humeral fractures. Clin Orthop Surg, 2014. 6(2): p. 146-52.

10. Aksu, N., et al., Minimally invasive plate osteosynthesis (MIPO) in diaphyseal humerus and proximal humerus fractures. Acta Orthop Traumatol Turc, 2012. 46(3): p. 154-60.

11. Ismail, H., et al., Minimal Invasive Plate Osteosynthesis (MIPO) Technique Using Anterolateral Approach for Treating Closed Proximal Humerus Fracture. Malays Orthop J, 2012. 6(1): p. 1824.
12. Zumstein, M.A., et al., Triceps-sparing extra-articular step-cut olecranon osteotomy for distal humeral fractures: an anatomic study. J Shoulder Elbow Surg, 2017. 26(9): p. 1620-1628.

13. Sane, A.D., et al., [Olecranon osteotomy in the treatment of distal humeral fractures in adults: anatomical and functional evaluation of the elbow in 14 cases]. Chir Main, 2009. 28(2): p. 93-8.

14. Hong, C.C., D.H. Hey, and D. Murphy, Evolving trends in surgically managed patients with proximal humerus fracture: are we different after ten years? Singapore Med J, 2014. 55(11): p. 5748.

15. Ortmaier R., et al., Comparison between minimally invasive, percutaneous osteosynthesis and locking plate osteosynthesis in 3-and 4-part proximal humerus fractures. BMC Musculoskelet Disord, 2015. 16: p. 297.

16. Beazley, J.C., et al., Distal Humeral Fractures-Current Concepts. Open Orthop J, 2017. 11: p. 1353-1363. 